\title{
KOBIETY U TERTULIANA W KONTEKŚCIE HISTORII ZBAWIENIA
}

Wraz z przyjściem na świat Jezusa Chrystusa zostaje dowartościowana osoba kobiety. W cywilizacji grecko-rzymskiej, czy też środowisku palestyńskim, gdzie kobiety w mniejszym lub większym stopniu podlegały ograniczeniom prawnym, dotyczącym życia społecznego i religijnego, stanowiło to swoistą rewolucję. Jezus nie czyni różnic i włącza kobiety na równi z mężczyznami do swojej misji ewangelizacyjnej. Mają one ogromny wkład w rozprzestrzenianie się Ewangelii ${ }^{1}$. Ponadto Nauczyciel z Nazaretu nigdy nie mówi ani słowem o słabości czy niższości kobiety względem mężczyzny.

Pomimo tego, iż w Ewangeliach postawa Jezusa względem kobiet jest pełna afirmacji i wyraża się w traktowaniu ich na równi z mężczyznami, rzecz staje się o wiele trudniejsza, gdy przyjrzymy się późniejszej interpretacji egzegetycznej Ojców Kościoła.

Stosunek Ojców Kościoła do kobiet, ich pozycji we wspólnocie, funkcji i ról im przynależących, nacechowany jest z jednej strony ewangelicznym przezwyciężeniem wszelkich różnic aksjologicznych między mężczyzną a kobieta, przynajmniej na płaszczyźnie duchowej, z drugiej jednak daje się zaobserwować przeświadczenie poszczególnych pisarzy o niższości kobiety,

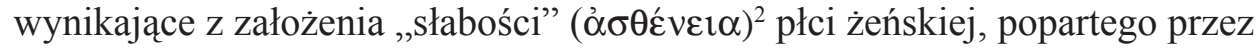
wiedzę ,medyczną" oraz opinie filozoficzne i ludowe ${ }^{3}$.

W niniejszym artykule, poprzez analizę pism Tertuliana, postaramy się zdefiniować postawę tegoż pisarza wobec kobiet w kontekście historii zbawienia.

\footnotetext{
${ }^{*}$ Ks. dr Dariusz Zalewski - wykładowca patrologii w Wyższym Seminarium Duchownym wEłku; e-mail: darekz@tiscali.it.

${ }^{1}$ Por. A. Weiser, Die Rolle der Frau in der urchristlichen Mission, w: Die Frau im Urchristentum, hrsg. G. Dautzenberg - H. Merklein - K. Müller, Freiburg 1983, 158-181.

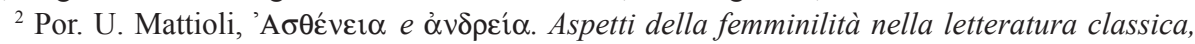
biblica e cristiana antica, Roma 1983.

${ }^{3}$ Por. E. Prinzivalli, Donna e generazione nei Padri della Chiesa, w: La donna nel pensiero cristiano antico, ed. U. Mattioli, Genova 1992, 79-94; D. Gourevitch, Le mal d'être femme. La femme et la médecine dans la Rome antique, Paris 1984; P.A. Gramaglia, La condizione femminile in Tertulliano, w: Tertulliano, De virginibus velandis. La condizione femminile nelle prime comunità cristiane, ed. tenże, Roma 1984, 182-192.
} 


\section{PRZYCZYNY PODPORZĄDKOWANIA KOBIETY MĘŻCZYŹNIE}

W pierwszej części artykułu zostaną przedstawione argumenty, którymi Tertulian posługuje się mówiąc o niższości natury kobiecej i podporządkowaniu jej mężczyźnie. Wszystkie one bazują na analizie tekstów Pisma Świętego, zwłaszcza opisie stworzenia człowieka (Rdz 1-3).

1. Wina za grzech pierworodny. Jest rzeczą oczywistą, że punktem odniesienia dla Ojców Kościoła przy zajmowaniu stanowiska wobec określonych tematów czy problemów było zawsze Pismo Święte. Jeśli chodzi o kwestie dotyczące kobiet, najczęściej przytaczanymi tekstami były fragmenty z Księgi Rodzaju, mówiące o dziele stworzenia mężczyzny i kobiety ${ }^{4}$, oraz z Corpus Paulinum. Pośród autorów, którzy jakkolwiek bez jakiegoś systematycznego komentarza pierwszych rozdziałów Księgi Rodzaju, lecz z licznymi i znaczącymi odniesieniami do sytuacji pierwotnej tam nakreślonej, tworzą obraz aktualnego stanu kobiety, silnie uwarunkowany wydarzeniami w raju, znajduje się bez wątpienia Tertulian.

Ewidentny przykład uzależnienia obecnej kondycji kobiety od wydarzeń protologicznych stosuje Tertulian we wstępie dzieła De cultu feminarum:

„Gdyby tu, na ziemi, istniała tak wielka wiara, jak wielka zapłata za nią jest oczekiwana w niebie, zgoła żadna z was, umiłowane siostry, z chwilą poznania Boga żywego i zrozumienia swego, to jest niewiasty stanu, nie pożądałaby stroju ładniejszego, a cóż dopiero wspanialszego, lecz każda żyłaby raczej w żałobie, a nawet zaniedbywałaby swój wygląd zewnętrzny, ponieważ wskazywałaby na siebie, jako na Ewę żałującą i pokutująca, aby przez wszelką odzież pokutną pewniej naprawiła to, co się ciągnie od Ewy; mam na myśli hańbę grzechu pierworodnego i niesławę upadku rodzaju ludzkiego. W bólach i trwodze rodzisz, niewiasto, i musisz trzymać się męża swego, a on jest twoim panem: i ty nie chcesz zrozumieć, że jesteś Ewą? Jest w mocy wyrok Boga nad twoją płcią na tym świecie: musi więc trwać dalej i twoja wina. Ty jesteś furtą szatana, ty dotknęłaś owego drzewa, ty pierwsza złamałaś boskie prawo; ty właśnie namówiłaś tego, do którego diabeł nie mógł się zbliżyć; $\mathrm{z}$ łatwością doprowadziłaś do upadku mężczyznę Adama, obraz Boga; przez twoją karę, to jest śmierć, nawet Syn Boży musiał umrzeć: a tobie przychodzi do głowy przyozdabiać swoją powłokę cielesną?"5.

${ }^{4}$ Por. G. Sfameni Gasparro, La donna nell'esegesi patristica di Gen 1-3, w: La donna nel pensiero cristiano antico, s. 17-50; taż, Donna e creazione negli scritti dei Padri: aspetti e problemi dell'esegesi patristica di Gen 1-3, w: Dizionario di Spiritualità Biblico-Patristica, ed. S.A. Panimolle, t. 11: Creazione, Uomo, Donna negli scritti dei Padri, Roma 1995, 217-239.

${ }^{5}$ Tertullianus, De cultu feminarum I 1, 1-2, ed. E. Kroymann, CCL 1, Turnhout 1954, 343: „Si tanta in terries moraretur fides, quanta merces expectatur in caelis, nulla omnino vestrum, sorores dilectissime, ex quo deum vivum cognovisset et de sua, id est feminae condicione didicisset, laetiorem habitum, ne dicam gloriosiorem appetisset, ut non magis in sordibus ageret et squalorem 
Kartagińczyk jest przekonany, że wydarzenia związane ze stworzeniem i grzechem popełnionym przez pierwszych ludzi wpłynęły w sposób decydujący na kondycję historyczną kobiety i w następstwie jej podporządkowanie mężczyźnie. W wyżej cytowanym fragmencie, mimo iż adresatki, do których jest kierowane dzieło, są nazwane „umiłowanymi siostrami”, jednocześnie są wezwane do uświadomienia sobie, że obecny ich stan wynika z wyboru, jakiego dokonała pierwsza kobieta. To właśnie po wydarzeniach w raju wszystkie kobiety odziedziczyły po Ewie „hańbę grzechu pierworodnego i niesławę upadku rodzaju ludzkiego". Ta spuścizna ze swej natury domaga się więc zadośćuczynienia oraz przyjęcia postawy pokutnej, odrzucającej wszelkie nadużycia w sferze ubioru i ozdób, aby w ten sposób, również poprzez ubranie zmazać hańbę grzechu pierworodnego.

Cała więc wina i odpowiedzialność za upadek w raju przypisana jest praktycznie Ewie: ,ty właśnie namówiłaś tego, do którego diabeł nie mógł się zbliżyć". Nie ma żadnej wzmianki, przynajmniej w przytoczonym powyżej fragmencie, o uczestnictwie w nim i odpowiedzialności Adama. Źródła powyższej interpretacji należy szukać w tradycji judaistycznej, a szczególnie w komentarzach rabinicznych i literaturze apokryficznej, odnoszących się do pierwszych rozdziałów Księgi Rodzaju. Ukazuje się w nich Ewę, jako przyczynę grzechu, który sprowadza śmierć, a z drugiej strony Adama, którego diabeł nie zdołał omamić. Ewa pozwala się zwieść i następnie zwodzi mężczyznę. Zostaje przedstawiona dwa razy w negatywnym świetle: jako „uwiedziona” i jako „uwodzicielka”.

2. Mężczyzna „obrazem Boga”. Podporządkowanie kobiety mężczyźnie według Tertuliana wynika również z faktu, że tylko Adam może cieszyć się

potius affectaret, ipsam se circumferens Evam lugentem et paenitentem, quo plenius id, quod de Eva trahit - ignominiam dico primi delicti et invidiam perditionis humanae - omni satisfactionis habitu expiaret. In doloribus et anxietatibus paris, mulier, et ad virum tuum conversio tua, et ille dominatur tui: et Evam te esse nescis? Vivit sententia dei super sexum istum in hoc saeculo: vivat et reatus necesse est. Tu es diaboli ianua, tu es arboris illius resignatrix, tu es divinae legis prima desertrix; tu es quae eum suasisti, quem diabolus aggredi non valuit; tu imaginem dei, hominem, tam facile elisisti; propter tuum meritum, id est mortem, etiam filius dei mori habuit: et adornari tibi in mente est super pelliceas tuas tunicas?”, tłum. D. Sutryk: Tertulian, O strojeniu się kobiet, w: Tertulian, Wybór pism, III, PSP 65, Warszawa 2007, 33.

${ }^{6}$ Por. R. Uglione, Donna e matrimonio in Tertuliano, w: tenże, Tertuliano. Teologo e scrittore, Brescia 2002, 81-82. Słabość natury kobiecej, wyrażającej się w łatwej możliwości zostania uwiedzioną, podkreślona jest także poprzez przywołanie przez Tertuliana (De cultu feminarum 1, 3, 1, CCL 1, 346, 358; De virginibus velandis 7, 2, ed. E. Dekkers, CCL 2, Turnhout 1954, 1216-1217; De idolatria 9,1, ed. A. Reifferscheid - G. Wissowa, CCL 2, 1107; Adversus Marcionem V 8, 2, ed. E. Kroymann, CCL 1, 685-686) motywu połączenia się aniołów z córkami ludzkimi. Wydarzenie to opisane jest w Księdze Henocha, która pomimo iż nie należy do kanonu Starego Testamentu, jest przez Kartagińczyka traktowana jako natchniona i swobodnie wykorzystywana, por. Sfameni Gasparro, La donna nell'esegesi patristica di Gen 1-3, s. 29. 
przywilejem bycia stworzonym na „obraz Boga"7. Taka interpretacja Rdz 1, 26 bierze swój początek z pewnością od apostoła Pawła. Jest również obecna w literaturze rabinicznej, zgodnie z którą większą wartość ma to, co zostało stworzone najpierw, a mniejszą to, co zostało stworzone później. Stąd tylko Adamowi, stworzonemu jako pierwszemu i bez pośrednictwa zostaje przyznane miano „obrazu Bożego”, podczas gdy Ewie, jako stworzonej po Adamie i po części z niego, taki atrybut nie przysługuje ${ }^{8}$.

Motyw mężczyzny jako „obrazu Boga” wykorzystuje Kartagińczyk w innym swoim dziele - De virginibus velandis. Powołując się na apostoła Pawła, który mówi, że „Mężczyzna nie powinien nakrywać głowy, bo jest obrazem i chwałą Boga, a kobieta jest chwałą mężczyzny" (1Kor 11, 7) uzasadnia on, w jaki sposób powinny zachowywać się kobiety, przede wszystkim dziewice, i dlaczego powinny nosić zasłony:

„Z tych wszystkich argumentów wydobywają dowody przeciw temu, by mężczyzna nie okrywał głowy, a mianowicie takie: że mężczyzna z natury nie osiąga obfitości włosów; że nie jest dlań haniebne golić się i się strzyc; że aniołowie nie przekroczyli prawa ze względu na niego; że «on jest chwałą i obrazem Boga»; że głową jego jest Chrystus" ".

Mężczyzna, będąc „obrazem i chwałą Boga” nie potrzebuje zakrywać swojej głowy, gdyż modląc się z odkrytą głową w ten sposób oddaje najwyższą cześć Bogu. Kobieta zaś, jako podporządkowana mężczyźnie, powinna modlić się z zasłoną na głowie.

3. Pochodzenie kobiety od mężczyzny. Również w De virginibus velandis zostaje podkreślone przez pisarza z Kartaginy pochodzenie kobiety z mężczyzny:

„Albowiem, kiedy Pismo podaje, że dwoje było nagich, Adam i jego kobieta, nie pojmuje tego na przyszłość, jakby powiedziało, że była jego kobietą, a żoną w przepowiedni, lecz że ona będzie z jego natury, bo jest i niezamężną jego kobietą. «Ta dopiero jest kością z moich kości - rzecze - i ciałem z mego ciała. Ta będzie się zwała kobietą» (Rdz 2, 23)"'10.

Wyższość Adama nad Ewą, a co za tym idzie także jej podporządkowanie, według naszego autora wynika nie tyle z faktu „słabości” natury kobiecej,

${ }^{7}$ Tertullianus, De cultu feminarum I 1, 2, CCL 1, 343, PSP 65, 33.

${ }^{8}$ Por. Uglione, Donna e matrimonio in Tertuliano, s. 83-84. Prawdopodobnie na tę zasadę powołuje się Paweł, kiedy mówi, że „To nie mężczyzna powstał z kobiety, lecz kobieta z mężczyzny. Podobnie też mężczyzna nie został stworzony dla kobiety, lecz kobieta dla mężczyzny" (1Kor 11, 7-8).

${ }^{9}$ Tertullianus, De virginibus velandis 8,1 , CCL 2, 1217, thum. K. Obrycki: Tertulian, O noszeniu zastony przez dziewice, PSP 65, 93.

${ }^{10}$ Tamże 5, 2, CCL 2, 1214: „Nam cum Scriptura refert fuisse nudos duos, Adam et mulierem eius, nec hoc de futuro sapit quasi mulierem dixerit eius in praesagio uxoris, sed quoniam et innupta illius mulier, ut de substantia ipsius: Hoc, inquit, os ex ossibus meis, et caro ex carne mea vocabitur mulier”, PSP 65, 90. Por. tamże 5, 3-4, CCL 2, 1214-1215; 7, 2, CCL 2, 1216-1217. 
która przejawiła się w uległości wężowi w raju, lecz raczej z odwiecznego planu Bożego, dotyczącego kreacji kobiety. Stąd też obowiązek noszenia zasłony, jako wyrazu podporządkowania, dotyczy nie tylko kobiet zamężnych, podległych swym mężom, ale także i dziewic, które wprawdzie nie są zamężne, ale są podporządkowane ze swej natury ${ }^{11}$.

Po grzechu pierworodnym, Bóg powodowany swoją sprawiedliwością sprawia, że kobieta musi znosić bóle rodzenia i podporządkować się panowaniu mężczyzny:

„Tak więc aż do grzechu człowieka Bóg był tak bardzo dobry od początku, a odtąd jest Sędzią i to surowym [...] bo natychmiast skazuje niewiastę na rodzenie w bólach i służenie mężowi [...]. Chociaż była przeznaczona do pomocy mężczyźnie, to nie do służby"12.

To dramatyczne wydarzenie zmieni radosną współpracę między kobietą i mężczyzną w bolesne panowanie tego ostatniego.

\section{TERTULIAN MIZOGINISTĄ?}

Na podstawie cytowanego przez nas wstępu De cultu feminarum $(1,1-2)$ wielu uczonych, zwłaszcza o feministycznych zapatrywaniach, twierdzi, że Tertulian był mizoginistą. Zwłaszcza wyrażenie „Tu es diaboli ianua”13, obarczające Ewę całą winą za grzech pierworodny, skłania ich do takiego przeświadczenia ${ }^{14}$. W swoich ocenach popełniają oni zasadniczy błąd, przyjmując jedno wyrażenie jako klucz do interpretacji całości nauki i myśli Afrykańczyka, abstrahując od szerszego kontekstu utworu, czy też pozostałych jego pism. Należy podkreślić, że nie był on systematycznym teologiem, a z drugiej

${ }^{11}$ Jak słusznie zauważa A. Łuźniak w swojej dysertacji doktorskiej (Matrimonio, verginità, vedovanza negli scritti di Q.S.F. Tertulliano, Roma 2008, 14), Tertulian, mówiąc o stworzeniu kobiety, używa słów „substantia” (De virginibus velandis 5, 2, CCL 2, 1214: „de substantia ipsius”; tamże 5, 3: „ex cuius substantia”) lub „materia” (Ad uxorem I 3, 1, ed. E. Kroymann, CCL 1, 375: „ex eiusdem materiae consortio”) mężczyzny. Adam, który został stworzony bezpośrednio przez Boga z prostej materii, jest podporządkowany tylko swemu Stwórcy, natomiast Ewa, także stworzona przez Boga, ale z materii pochodzącej od Adama, musi być podporządkowana temu, od którego bierze swój początek. Dla Kartagińczyka więc podporządkowanie kobiety mężczyźnie nie jest wynikiem jej obecnej kondycji społecznej, jako np. osoby zamężnej, lecz wiąże się z odwiecznym planem Boga, który wpisany zostaje w naturę kobiety już na samym początku.

${ }^{12}$ Tertullianus, Adversus Marcionem II 11, 1, CCL 1, 488: „Igitur usque ad delictum hominis, deus a primordio tantum bonus, exinde iudex et severus [...] statim mulier in doloribus parere, et viro servire damnatur [...] sed quae in adiutorium masculo, non in servitium fuerat destinata", thum. S. Ryznar: Tertulian, Przeciw Marcjonowi, PSP 58, Warszawa 1994, 82.

${ }^{13}$ Tenże, De cultu feminarum I 1, 2, CCL 1, 343.

${ }^{14}$ Por. E.S. Fiorenza, In Memory of Her: a feminist theological reconstruction of Christian origins, London 1983, 55; M. Turcan, Etre femme selon Tertullien, „Vita Latina” 119 (1990) 15-21; A. Cameron, Early Christianity and the Discourse of Female Desire, w: Women in Ancient Societies: An Illusion of the Night, ed. L.J. Archer - S. Fischler - M. Wyke, London 1994, 153. 
strony nie można zapominać o wpływie, jaki na jego dzieła miało retoryczne wykształcenie. Bardzo często wykorzystywał on sztukę retoryki starożytnej, by uczynić swoje argumenty bardziej przekonującymi ${ }^{15}$.

W tym miejscu zostaną przytoczone te fragmenty z dzieł Tertuliana, z których jasno wynika, że nie był on zdeklarowanym mizoginistą. Co więcej, pod pewnymi względami uznawał równość kobiet i mężczyzn. W tych fragmentach Kartagińczyk odwołuje się do Pisma Świętego, moralności i eschatologii.

1. Wspólna odpowiedzialność za grzech pierworodny. Nie jest prawda, że odpowiedzialność za grzech pierworodny według Tertuliana, ponosi tylko Ewa. W innych miejscach nasz autor widzi Adama jako głównego protagonistę tego wydarzenia:

„Adam, założyciel rodu ludzkiego i sprawca grzechu zechciał zgrzeszyć. Diabeł bowiem nie przekazał mu woli grzeszenia, lecz podsunął jego woli to, w czym zgrzeszył"16.

Ponadto Kartagińczyk, jako zwolennik traducjanizmu materialistycznego, twierdził, że każda dusza wywodzi się z ojca razem z ciałem, z którym jest zjednoczona ${ }^{17}$. Wprawdzie nie mówił wprost, że grzech pierworodny jest przekazywany drogą traducjanizmu, jednakże podkreślał, że dusza rodzi się w grzechu pierworodnym ${ }^{18}$.

2. Kobieta również „obrazem Boga”. Podobnie ma się rzecz z przyznaniem wyłącznie Adamowi tytułu stworzenia na „obraz Boga”. W De virginibus velandis Afrykańczyk zdaje się przyznawać również kobiecie atrybut „obrazu Bożego”, wprawdzie mniej „wiernego” niż w przypadku mężczyzny, ale jednak obrazu:

„Jakże więc Bóg zgodziłby się na coś takiego, uznając za cześć tak samo dla mężczyzn - jako że mężczyzna jest wierniejszym Jego obrazem, albo że jest bardziej pracowitym Jego obrazem?"'19.

${ }^{15}$ Por. D.M Cooper, Was Tertullian a Misogynist? A re-examination of this charge based on a rhetorical analysis of Tertullian's work, Exeter 2012.

${ }^{16}$ Tertullianus, De exhortatione castitatis 2, 5, ed. E. Kroymann, CCL 2, 1017, thum. K. Obrycki, PSP 29, Warszawa 1983, 166. Por. tenże, Adversus Marcionem II 8, 2, CCL 1, 484: „sicut Deus homini vitae statum induxit, ita homo sibi mortis statum adtraxit [...]. Nam etsi angelus qui seduxit, sed liber et suae potestatis qui seductus est, sed imago et similitude dei (Adam) fortior angelo (diabolo)".

${ }^{17}$ Por. tenże, De anima I 1-22, ed. J.H. Waszink, CCL 2, 781-814.

${ }^{18}$ Por. C.E. Freppel, Tertullien. Cours d'éloquence sacrée fait à la Sorbonne pendant l'année 1861-1862, Paris 1887, 344-348.

19 Tertullianus, De virginibus velandis 10, 4, CCL 2, 1220: „Quomodo ergo non magis viris aliquid tale Deus in honorem subscripsisset vel quia familiariori scilicet imagini suae, vel quia plus laboranti?", PSP 65, 96. 
Zdaniem F. Forrester Church ${ }^{20}$, nawet jeśli Tertulian w sposób wyraźny nie mówi o kobiecie jako stworzonej na „obraz Boży”, to w sposób domyślny przyznaje jej „podobieństwo”. Badacz wychodzi tutaj od rozróżnienia, jakie Kartagińczyk czyni między „imago”, który jest właściwy człowiekowi poprzez naturę, a „similitudo", które pochodzi z łaski, zostaje utracone wraz z grzechem pierworodnym i przywrócone przez chrzest ${ }^{21}$.

3. Męstwo kobiet. Dowodem braku niechęci wobec rodzaju żeńskiego jest również fakt, że w swoich pismach Kartagińczyk nie waha się przywoływać przykłady kobiet, które mimo słabej natury, zdolne były stanąć w obronie najwyższych wartości moralnych, poświęcając nawet swoje życie ${ }^{22}$. W sposób szczególny na uznanie zasługują męczenniczki chrześcijańskie, które odznaczyły się męstwem podczas tortur:

„co począłbyś, gdyby stawiło się przed tobą tyle tysięcy ludzi, tak wiele mężczyzn i kobiet, osób obojga płci, każdego wieku, wszelkiej godności? Ilu stosów potrzebowałbyś, ilu mieczy? Co musiałaby wycierpieć sama Kartagina,

${ }^{20}$ Por. F.F. Church, Sex and Salvation in Tertullian, HTR 68 (1975) fasc. 2, 89-91.

${ }^{21}$ Por. Tertullianus, De baptismo 5, 7, ed. J.G.Ph. Borleffs, CCL 1, 282: „Ita restituitur homo deo ad similitudinem eius, qui retro ad imaginem dei fuerat - imago in effigie, similitudo in aeternitate censetur - recipit enim illum dei spiritum quem tunc de adflatu eius acceperat sed post amiserat per delictum".

${ }^{22}$ Por. tenże, Ad martyras 4, 3-6, ed. E. Dekkers, CCL 1, 6-7: „Sed spiritus contraponat sibi et carni: acerba licet ista, a multis tamen aequo animo excepta, immo et ultro appetita, famae et gloriae causa; nec a viris tantum, sed etiam a feminis, ut vos quoque, benedictae, sexui vestro respondeatis. Longum est, si enumerem singulos, qui se gladio confecerint, animo suo ducti. De feminis ad manum est Lucretia, quae vim stupri passa cultrum sibi adegit in conspectu propinquorum, ut gloriam castitati suae pareret [...]. Dido, ne post virum dilectissimum nubere cogeretur; item Asdrubalis uxor, quae iam ardente Carthagine, ne maritum suum supplicem Scipionis videret, cum filiis suis in incendium patriae devolavit [...]. Bestias femina libens appetiit, et utique aspides, serpentes tauro vel urso horridiores, quas Cleopatra immisit sibi, ne in manus inimici perveniret"; tenże, De monogamia 17, 2-4, ed. E. Dekkers, CCL 2, 1252: „Exsurget regina Carthaginis et decernet in Christianas, quae profuga et in alieno solo et tantae civitatis cum maxime formatrix, cum regis nuptias ultro optasse debuisset, ne tamen secundas eas experiretur, maluit e contrario uri quam nubere. Assidebit et illi matrona Romana, quae etsi per vim nocturnam nihilominus experta alium virum maculam carnis suo sanguine abluit, ut monogamiam in semetipsam vindicaret. Fuerunt et quae pro viris mori mallent quam post viros nubere. Idolis certe et monogamia et viduitas apparent. Fortunae Muliebri coronam non imponit nisi univira, sicut Matri Matutae. Pontifex Maximus et Flaminica nubunt semel. Cereris sacerdotes viventibus etiam viris et consentientibus amica separatione viduantur. Sunt et quae de tota continentia iudicent nos, virgines Vestae et Iunonis Achaicae et Dianae Scythicae et Apollinis Pythii. Etiam bovis illius Aegyptii antistites de continentia infirmitatem Christianorum iudicabunt"; tenże, Apologeticum, 50, 5 i 8, ed. E. Dekkers, CCL 1, 170; tenże, Ad uxorem I 6, 3-4, CCL 1, 380; tenże, De exhortatione castitatis 13, 1-3, CCL 2, 1033-1034; C. Tibiletti, La donna in Tertulliano. Misoginia e maschilismo in Grecia e in Roma, Genova 1981, 93. 
gdyby została tak zdziesiątkowana przez ciebie, gdyby każdy zastał wśród nich swoich krewnych, czy swoich domowników, mężów i kobiety twego stanu"23.

Wielkim poważaniem Tertuliana cieszą się ponadto dziewice i wdowy, które powstrzymując się od przyjemności, odznaczają się autentycznym męstwem i odnoszą zwycięstwo nad swoją seksualnością. Pisząc do swojej żony, Afrykańczyk zachęca ją do pozostania wdową na wypadek, gdyby on umarł wcześniej. Wychwala ponadto przykłady innych kobiet, które poprzez swoją wstrzemięźliwość uśmierciły popędy ciała:

„pójdź za przykładem naszych sióstr, których imiona zapisane są u Pana; one bowiem po utracie mężów nie korzystają już z żadnej okazji do zamążpójścia [...]. Wolą raczej zaślubić się z Bogiem. Dla Boga są piękne, dla Boga są młodymi dziewczętami. Z Nim żyją, z Nim rozmawiają, z Nim przestają we dnie i w nocy, Jemu jako swemu Panu przynoszą modlitwę swoją w posagu, od Niego otrzymują właściwe uznanie jako prezent ślubny, ilekroć tego zapragną"24.

4. Uczestnictwo kobiet w charyzmatach. Tertulian, który z jednej strony odmawia kobietom uczestnictwa w służbie kapłańskiej ${ }^{25}$, z drugiej jednak przyznaje, że są one zdolne na równi z mężczyznami do otrzymywania zaszczytnych charyzmatów, jak chociażby daru prorokowania:

„Jest dzisiaj pośród nas siostra, która otrzymała charyzmaty proroctwa, których doświadcza w kościele $\mathrm{w}$ duchowej ekstazie, podczas uroczystości niedzielnych. Rozmawia z aniołami, czasem także z Panem. Widzi i słyszy tajemnice, ma wgląd w serca niektórych i otrzymuje wskazówki dla tych, którzy pragną być uzdrowieni”"26.

Kategorią uprzywilejowaną tego daru, wychwalaną przez Kartagińczyka, są również dziewice i wdowy.

5. Zbawienie. Według Tertuliana, kobiety są zrównane z mężczyznami w kontekście zbawienia. Po zmartwychwstaniu przypisuje on im status identyczny do tego, który posiadają mężczyźni: one również będą, jak aniołowie w niebie:

${ }^{23}$ Tertullianus, Ad Scapulam 5, 2, ed. E. Dekkers, CCL 2, 1132, thum. W. Myszor, PSP 29, 115.

${ }^{24}$ Tenże, Ad uxorem I 4, 3-4, CCL 1, 377, thum. K. Obrycki, PSP 29, 150-151. Por. tenże, De exhortatione castitatis 13, 4, CCL 2, 1035; tenże, De resurrectione mortuorum 61, 6, ed. J.G.Ph. Borleffs, CCL 2, 1010.

${ }^{25}$ Por. tenże, De virginibus velandis 9,1, CCL 2, 1218-1219.

${ }^{26}$ Tenże, De anima I 9, 4, CCL 2, 792, tłum. własne. Por. tenże, De oratione 21, 4, ed. G.F. Diercks, CCL 1, 268; tenże, Adversus Marcionem V 8, 11-12, CCL 1, 688; tenże, De virginibus velandis 17, 3, CCL 2, 1226; tenże, De resurrectione mortuorum 11, 2, CCL 2, 933; tenże, De exhortatione castitatis 10, 5, CCL 2, 1030; tenże, Adversus Praxean 1, 5, ed. E. Kroymann - E. Evans, CCL 2, 1159. 
„Albowiem i wam także obiecana na ten czas natura wspólna z aniołami i płeć wspólna z mężczyznami, zapewnia tę samą godność sędziowską"27.

W swoim dziele De resurrectione mortuorum Kartagińczyk wyjaśnia, że zmartwychwstanie ciała dokona się z zachowaniem rozróżnienia płciowego ${ }^{28}$. Jednakże po zmartwychwstaniu członki ciała, zarówno męskiego, jak i kobiecego, nie będą już spełniać funkcji, które były im przypisane podczas życia ziemskiego $^{29}$. Co więcej, już tutaj na ziemi, dzięki postowi i wstrzemięźliwości, członki te mogą służyć do wyższych celów ${ }^{30}$.

Jak więc można zaobserwować, w swoich pismach Tertulian nie żywi nienawiści do kobiet, nie ma zamiaru ich potępiać czy przedstawiać w negatywnym świetle, jako osoby posiadające niższą naturę. Jego zamiarem jest szukanie ich dobra, nawet jeśli czasami w swojej argumentacji musi odwołać się do ukazania negatywnej strony natury kobiet. Nie jest on pisarzem, który notorycznie wyszukuje i wskazuje na wszystko to, co jest negatywne w naturze kobiecej. Wszystkie przejawy nieufności do płci żeńskiej wynikają raczej z jego charakteru i skłonności do rygoryzmu moralnego oraz po części odzwierciedlają mentalność ludzi, którzy tworzyli wspólnoty chrześcijańskie w II i III wieku ${ }^{31}$, i nie są przejawem, jak chcą niektórzy, obsesyjnej, mizoginistycznej postawy pisarza ${ }^{32}$.

Tertulian czyni wszystko dla dobra kobiet i nawet jeśli początek De cultu feminarum zdaje się temu przeczyć, gdyż pisarz używa tutaj dosadnych słów w stosunku do płci żeńskiej, to jednak ostatnie słowa tego traktatu rozwiewają wszelkie wątpliwości:

${ }^{27}$ Tenże, De cultu feminarum I 2, 5, CCL 1, 346, PSP 65, 36; por. Church, Sex and Salvation in Tertullian, s. 99. Pisząc o wdowach, ale należałoby tu wymienić także dziewice, Tertulian podkreśla, że przez swoją wstrzemięźliwość tworzą one już tutaj na ziemi rodzinę anielską; por. Tertullianus, Ad uxorem I 4, 4, CCL 1, 377: „Sic aeternum sibi bonum, donum domini, occupauerunt, ac iam in terris non nubendo de familia angelica deputantur".

${ }^{28}$ Por. E. Prinzivalli, Early Christian Antropology: Gender Models in Creation and Resurrection, w: Christian and Islamic Gender Models, ed. K.E. Børresen, Roma 2004, 43-65.

${ }^{29}$ Por. Tertullianus, De resurrectione mortuorum 60, 3, CCL 2, 1008: „Quo renes, conscii seminum, et reliqua genitalium utriusque sexus et conceptuum stabula et uberum fontes, decessuro concubitu et fetu et educatu?".

${ }^{30}$ Por. tamże 61, 4-7, CCL 2, 1010: ,Sublata enim morte neque victus fulcimenta ad praesidia vitae neque generis subparatura gravis erit membris. Ceterum et hodie vacare intestinis et pudendis licebit [...]. Nos quoque, ut possumus, os $<\mathrm{a}>$ cibo excusamus; etiam sexum a congressione subducimus. Quot spadones voluntarii, quot virgins Christi maritae, quot steriles utriusque naturae infructuosis genitalibus structi? Nam si et hic iam vacare est et officia et emolumenta membrorum temporali vacatione, ut in temporali dispositione, nec homo tamen minus salvus est, proinde homine salvo, et quidem magis tunc ut in aeterna dispositione, magis non desiderabimus quae iam hic non desiderare consuevimus".

${ }^{31}$ Por. M.G. Mara, I Padri della Chiesa e la donna, „Parole di Vita” 30 (1985) 416-417.

${ }^{32}$ Por. Łuźniak, Matrimonio, verginità, vedovanza negli scritti di Q.S.F. Tertulliano, s. 17, nota 10. 
„Wystapcie więc ozdobione farbami i kosztownościami proroków i apostołów, biorąc biel od prostoty, czerwień od wstydliwości, mając oczy umalowane skromnością, a usta milczeniem; w uszy wkładajcie słowa boże, a na karku miejcie nałożone jarzmo Chrystusa. Poddajcie głowę mężom waszym, a będziecie dosyć ozdobione. W ręce weźcie wełnę, nogi utwierdźcie w domu, i wówczas będą się bardzie podobały, niż w złocie. Ubierzcie się w jedwab sprawiedliwości, w len świętości i purpurę czystości. Kobiety tak wystrojone spotkają się z miłością ze strony Boga"33.

W powyższym fragmencie widoczna jest troska, jaką autor dzieła roztacza nad kobietami chrześcijańskimi, a w sposób szczególny ich ubiorem. Krytykując zbytnie ich przywiązanie do dbałości o wygląd zewnętrzny w stroju, fryzurze i ozdobach, Tertulian pragnie zwrócić uwagę na cnotę obyczajności, jaka powinna charakteryzować każdego chrześcijanina. Powinien on także poprzez ubiór odróżniać się od pogan, którzy przykładali wielką wagę do zewnętrznego wyglądu ${ }^{34}$. Tylko odrzucając ziemskie ozdoby kobiety spotkają się z miłością ze strony Boga ${ }^{35}$.

\section{$* * *$}

Podsumowując powyższe rozważania należy stwierdzić, że wizja kobiety, jaką w swoich pismach przedstawia Tertulian, daleka jest od jednoznaczności. Lektura jego dzieł nastręcza wiele trudności i może prowadzić nawet do wrażenia sprzeczności występujących w wypowiedziach autora. Z jednej strony Afrykańczyk wydaje się być zaciętym wrogiem kobiet, gdyż chociażby w De cultu feminarum czy De virginibus velandis w relacji do swoich adresatek posługuje się językiem ciętym, niejednokrotnie z emfazą retoryczną. Kiedy indziej natomiast, jak w De resurrectione mortuorum, kobiety zostają przez niego dowartościowane i stawiane na równi z mężczyznami, jako uczestniczące ciałem i duszą w Bożym odkupieniu i powszechnym zmartwychwstaniu $^{36}$. Brak niechęci naszego autora do kobiet widać w sposób ewidentny

${ }^{33}$ Tertullianus, De cultu feminarum II 13, 7, CCL 1, 370: „Prodite vos iam medicamentis et ornamentis extructae prophetarum et apostolorum, sumentes de simplicitate candorem, de pudicitia ruborem, depictae oculos uerecundia et os taciturnitate, inserentes in aures sermonem dei, adnectentes ceruicibus iugum Christi. Caput maritis subicite, et satis ornatae eritis. Manus lanis occupate, pedes domi figite et plus quam in auro placebunt. Vestite vos serico probitatis, byssino sanctitatis, purpura pudicitiae. Taliter pigmentatae Deum habebunt amatorem", PSP 65, 56. Por. A. Lamirande, Tertullien misogyne? Pour une relecture du „,De cultu feminarum”, ,Science et Esprit” 39 (1987) 23.

${ }^{34}$ Por. Tertullianus, De cultu feminarum II 4, 2, CCL 1, 357.

${ }^{35}$ Por. tamże 2, 13, 7, CCL 1, 370.

${ }^{36}$ Por. P.F. Moretti, La Bibbia e il discorso dei Padri Latini sulle donne. Da Tertulliano a Girolamo, w: Le donne nello sguardo degli antichi autori cristiani. L'uso dei testi biblici nella costruzione dei modelli femminili e la riflessione teologica del I al VII secolo, ed. K.E. Børresen - E. Prinzivalli, Trapani 2013, 138. 
w traktacie Ad uxorem, gdzie zwraca się on do swojej żony jako „najdroższej w Panu współtowarzyszki" ${ }^{37}$.

Dokonana analiza dzieł Tertuliana prowadzi więc do konkluzji, że aby poznać całokształt myślenia Kartagińczyka na temat kobiet, ale również i innych zagadnień, jak chociażby jego stosunku do filozofii, należy patrzeć szerzej, na kontekst wypowiedzi i całość twórczości autora, gdzie poruszane są podobne tematy. Nie można przy tym zapomnieć o jego zamiłowaniu do retoryki, której techniki szeroko wykorzystywał w swojej argumentacji. Wszystko to, w połączeniu z charakterem Kartagińczyka, skłonnym do moralnego rygoryzmu, czyni lekturę jego pism ekstremalnie trudną, a wydawanie jednoznacznych opinii, dotyczących pojmowania przez niego określonych zagadnień, nakazuje zachować daleko idącą ostrożność.

\section{WOMEN IN TERTULLIAN'S WORKS IN THE CONTEXT OF HISTORY OF SALVATION}

\section{(Summary)}

The analysis of the writings of Tertullian at an angle of his attitude towards women encounters a lot of difficulties. On one side when addressing to women he uses rather waspish, incisive language sometimes even with a rhetorical emphasis. We can see it at some instructive, moral fragments of the letters such as De cultu feminarum or De virginibus velandis. Superficial reading of these versets could lead up to a conclusion about antifeminism of Tertullian. On the other side he highly appreciates women because of their participation by body and sole at the God's redemption and universal resurrection. It is clearly seen at some of his theological works such as, for example, De resurrectione mortuorum.

Tertullian is not a writer who habitually looks for and show every negative characteristic feature of woman's character. All his manifestations of distrust towards women derive rather from his own character and prepossession to moral rigorism and partially reflect psyche of people constituting Christian communities at II and III centuries after Christ. At the same time we could say that the apparent discrepancy of his point of view towards women results not only from gradual changing of his attitude to women but mainly from the character of his works and aims he wanted to achieve.

Key words: Tertullian, woman, History of Salvation.

Słowa kluczowe: Tertulian, kobieta, Historia Zbawienia.

${ }^{37}$ Tertullianus, Ad uxorem I 1, 1, CCL 1, 373, PSP 29, 147. 


\section{BIBLIOGRAFIA}

\section{Źródła}

Tertullianus, Ad martyras, ed. E. Dekkers, CCL 1, Turnholti 1954, 1-8, thum. E. Stanula: Tertulian, Do męczenników, w: Tertulian, Wybór pism, PSP 5, Warszawa 1970, 31-39. Tertullianus, Ad Scapulam, ed. E. Dekkers, CCL 2, Turnholti 1954, 1125-1132, thum. W. Myszor: Tertulian, Do Skapuli, w: Tertulian, Wybór pism, II, PSP 29, Warszawa 1983, 109-116.

Tertullianus, Ad uxorem, ed. E. Kroymann, CCL 1, Turnholti 1954, 371-394, tłum. K. Obrycki: Tertulian, Do żony, w: Tertulian, Wybór pism, II, PSP 29, Warszawa 1983, 147-164.

Tertullianus, Adversus Marcionem, ed. E. Kroymann, CCL 1, Turnholti 1954, 441-726, thum. S. Ryznar: Tertulian, Przeciw Marcjonowi, PSP 58, Warszawa 1994.

Tertullianus, Adversus Praxean, ed. E. Kroymann - E. Evans, CCL 2, Turnholti 1954, 1159-1205, tłum. E. Buszewicz: Tertulian, Przeciw Prakseaszowi, w: Trójca Święta. Tertulian, Przeciw Prakseaszowi, Hipolit, Przeciw Noetosowi, ŹMT 4, Kraków 1996, $35-86$.

Tertullianus, Apologeticum, ed. E. Dekkers, CCL 1, Turnholti 1954, 77-171, thum. J. Sajdak: Tertulian, Apologetyk, POK 20, Poznań 1947.

Tertullianus, De anima, ed. J.H. Waszink, CCL 2, Turnholti 1954, 781-869.

Tertullianus, De cultu feminarum, ed. A. Kroymann, CCL 1, Turnhout 1954, 341-370, tłum. D. Sutryk: Tertulian, O strojeniu się kobiet, w: Tertulian, Wybór pism, III, PSP 65, Warszawa 2007, 33-56.

Tertullianus, De exhortatione castitatis, ed. E. Kroyman, CCL 2, Turnholti 1954, $1013-$ 1035, tłum. K. Obrycki: Tertulian, Zachęta do czystości, w: Tertulian, Wybór pism, II, PSP 29, Warszawa 1983, 165-181.

Tertullianus, De monogamia, ed. E. Dekkers, CCL 2, Turnholti 1954, 1227-1254, tłum. E. Stanula: Tertulian, O jednożeństwie, w: Tertulian, Wybór pism, III, PSP 65, Warszawa 2007, 59-82.

Tertullianus, De oratione, ed. G.F. Diercks, CCL 1, Turnholti 1954, 257-274, thum. W. Kania: Tertulian, O modlitwie, w: Tertulian, Wybór pism, PSP 5, Warszawa 1970, 114-132.

Tertullianus, De resurrectione mortuorum, ed. J.G.Ph. Borleffs, CCL 2, Turnholti 1954, 919-1012.

Tertullianus, De virginibus velandis, ed. E. Dekkers, CCL 2, Turnholti 1954, 1207-1226, thum. K. Obrycki: Tertulian, O noszeniu zasłony przez dziewice, w: Tertulian, Wybór pism, III, PSP 65, Warszawa 2007, 85-103.

\section{Opracowania}

Cameron A., Early Christianity and the Discourse of Female Desire, w: Women in Ancient Societies: An Illusion of the Night, ed. L.J. Archer - S. Fischler - M. Wyke, London 1994, 152-168.

Church F.F., Sex and Salvation in Tertullian, HTR 68 (1975) fasc. 2, 89-101.

CoOper D.M, Was Tertullian a Misogynist? A re-examination of this charge based on a rhetorical analysis of Tertullian's work, Exeter 2012.

Fiorenza E.S., In Memory of Her: a feminist theological reconstruction of Christian origins, London 1983. 
Freppel C.E., Tertullien. Cours d'éloquence sacrée fait à la Sorbonne pendant l'année 1861-1862, Paris 1887.

Gourevitch D., Le mal d'être femme. La femme et la médecine dans la Rome antique, Paris 1984.

Gramaglia P.A., La condizione femminile in Tertulliano, w: Tertulliano, De virginibus velandis. La condizione femminile nelle prime comunità cristiane, ed. tenże, Roma 1984, 174-214.

Lamirande A., Tertullien misogyne? Pour une relecture du „De cultu feminarum”, „Science et Esprit” 39 (1987) 5-25.

ŁuŹNIAK A., Matrimonio, verginità, vedovanza negli scritti di Q.S.F. Tertulliano, Roma 2008.

Mara M.G., I Padri della Chiesa e la donna, „Parole di Vita” 30 (1985) 411-419.

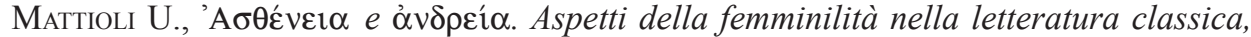
biblica e cristiana antica, Roma 1983.

Moretti P.F., La Bibbia e il discorso dei Padri Latini sulle donne. Da Tertulliano a Girolamo, w: Le donne nello sguardo degli antichi autori cristiani. L'uso dei testi biblici nella costruzione dei modelli femminili e la riflessione teologica del I al VII secolo, ed. K.E. Børresen - E. Prinzivalli, Trapani 2013, 137-173.

Prinzivalli E., Donna e generazione nei Padri della Chiesa, w: La donna nel pensiero cristiano antico, ed. U. Mattioli, Genova 1992, 79-94.

Prinzivalli E., Early Christian Antropology: Gender Models in Creation and Resurrection, w: Christian and Islamic Gender Models, ed. K.E. Børresen, Roma 2004, 43-65.

Sfameni Gasparro G., La donna nell'esegesi patristica di Gen 1-3, w: La donna nel pensiero antico, ed. U. Mattioli, Genova 1992, 17-50.

Sfameni Gasparro G., Donna e creazione negli scritti dei Padri: aspetti e problemi dell'esegesi patristica di Gen 1-3, w: Dizionario di Spiritualità Biblico-Patristica, ed. S.A. Panimolle, t. 11: Creazione, Uomo, Donna negli scritti dei Padri, Roma 1995, 217-239.

Tibiletti C., La donna in Tertulliano. Misoginia e maschilismo in Grecia e in Roma, Genova 1981.

Turcan M., Etre femme selon Tertullien, „Vita Latina” 119 (1990) 15-21.

Uglione R., Donna e matrimonio in Tertuliano, w: tenże, Tertuliano. Teologo e scrittore, Brescia 2002, 75-111.

Weiser A., Die Rolle der Frau in der urchristlichen Mission, w: Die Frau im Urchristentum, hrsg. G. Dautzenberg - H. Merklein - K. Müller, Freiburg 1983, 158-181. 
